\title{
I sing of Te Aitu o Te Rangi and the power of song to rejuvenate the principles, values and philosophy of Mana Wahine
}

\author{
SOPHRONIA SMITH
}

\begin{abstract}
I will sing of my tipuna wahine, Te Aitu o Te Rangi, daughter of Rangitane o Wairarapa chief, Te Whatahoronui. She was a beautiful young fourteen year old when the Ngāti Toa Chief Te Rauparaha successfully conquered the area and took her as a slave wife. Two years later Te Aitu and John Jury escaped Kapiti Island, where she was held captive and journeyed on a two man whaling boat back to Wairarapa. She was courageous amidst impending death on the turbulent waters of Wairarapa. She was also the mother of one of the most prolific writers, researchers and academic from Wairarapa, Hoani Te Whatahoro Jury, whose work ensured the preservation of knowledge regarding kauwae runga kauwae raro. In performing original contemporary composition, I celebrate the accomplishments of Te Aitu o Te Rangi, a Tuawahine, and I recall and embody the power of my matrilineal genealogy. Mana wahine stands strong in the spaces where feminist discourse continues to dominate, and composition provides a platform on which to reclaim and rewrite difference. My paper will look at the medium of contemporary music to provoke recognition and critique of the western archetype of the heroine, whilst at the same time advocating for social change.
\end{abstract}




\section{The meaning of Composition}

Composition is about our identity as Māori people. The stories we tell with words, actions, emotion, and creativity are intrinsic to the connection we have with our tupuna, and our world. Our compositions are key to the preservation of Te Reo Māori, knowledge transmission, and political commentary among others things. Neruda refers to oral knowledge transmission here:

The word

Was born in the blood

Grew in the dark body, beating

And flew through the lips and the mouth.

(Cited in Eisner 2004: 149)

He writes of the word as the first system of history transmission. Allen and Montell (1981) tell us that oral traditions can be seen to hold information about tribal knowledge, lore, protocols and practices in ways that are distinct from the information in written records. Oral transmission contains metaphorical, symbolical language that adds additional layers and context that the written word does not capture. Te Kāhautu Maxwell describes the importance of transmitting knowledge as the primary concern for him in relation to kapa haka. He adds that composition is a method for ensuring the survival of tribal knowledge and retaining this for the next generation (cited in Ka'ai, p. 125).

Composition acts as an archive of historical, cultural and tribal life. The creative expression of waiata and song has the ability to embody narratives that reflect notions of a Māori worldview, including the contribution and responsibility of women in traditional Māori society. Composition imbued with this knowledge is part of the Tino Rangatiratanga resolve and challenges beliefs about the roles of women as perpetuated by the West. Mikaere (2011) defines a Māori worldview in this way: 
The world view bequeathed to us by our ancestors is at the very heart of what makes us unique. It provides a lens through which we view the world and determines the way in which we relate to one another and all other facets of creation. It enables us to explain how we came to be here and all other facets of creation. It enables us to explain how we came to be here where we are going. It forms the very core of our identity (p.308).

The representation of Māori women, as with other indigenous women across the world, was directly affected by colonisation. For example, Best (1924) in his book entitled The Maori as he was, attributed negative, dark and almost evil attributes to Māori Atua Wahine. His negative representation of Atua Wahine gave justification for non-inclusion of Atua Wahine in history, the mana she wielded and the key responsibilities she held within the Māori world.

Composition is a space that allows us to rewrite difference and to speak back.

\section{Composition as a site of resistance}

Before Pākeha arrived on the shores of Aotearoa, the Māori language was oral. Waiata with its articulations of anger, hatred, sadness, love and desire, continues to serve as a medium by which cultural knowledge has been preserved and passed down. As such, Waiata can be seen as a tribal archive that recalls the past (McRae, 2004). Intrinsically bound to Māori identity, the performance of waiata reflects and reinforces a Māori worldview, its values and principles, and in doing has the potential to challenge Western discourse. Donna Grant ${ }^{1}$ tells us

Donna Grant is from Te Arawa and is an experienced kapa haka performer, teacher and composer.

Te Kaharoa, Special Edition, Ka Haka - Empowering Performance: Māori and Indigenous Performance Studies Symposium, vol. 9, 2016, 
that waiata and haka are mediums by which to create conscious knowledge about political issues. She states:

\begin{abstract}
All compositions are politically significant as they all tell a story ... we need many stories so that we can understand so that we can be inspired, to right injustices, to celebrate, to love, to forgive ... we are always making a comment about how we think about how we feel, and haka is just a natural medium that allows us to transmit the information ... korero is sometimes an ineffective method of getting the message across. (as cited in Ka'ai, 2006, p. 187)
\end{abstract}

Waiata and haka are useful in identifying causes with a hope that such recognitions can create greater consciousness. Composition provides whānau, hapū, and iwi with an opportunity to communicate and express ideas, to debate, to talk against wrongs that have been conducted.

Revitalising the stories of Atua Wahine and Tuawahine are part of a process of decolonising and demystifying the construction of western constructs of the heroine. Pihama (1994) describes such acts as key components of a process that is inherently political, contesting archetypal representations of the Western heroine. The potential of such an approach is not only a decolonizing methodology (Smith, 1999) that seeks to influence the resurrecting of stories of Atua Wahine and Tuawahine; it provides an opportunity to regenerate cultural ways of knowing. This is part of the Tino Rangatiratanga process.

\title{
Contemporary Māori Music
}

Contemporary popular music is one approach to converting Māori knowledge and thought into action that has relevance to 
us now. Innovation is required and is imperative to our survival, as Te Ahukaramū Charles Royal (2002) tells us:

\begin{abstract}
A key aspiration of all indigenous people is cultural survival. This means the perpetuation of our knowledge, our traditions, our worldviews, and our philosophies. What this requires, however, is not so much the simple use of traditional knowledge but research into its principles, its fundamental view on reality and the creative application of those views in the contemporary context. Otherwise, indigenous knowledge will remain merely historical phenomena, a museum curio bearing little relevance to the contemporary experience of indigenous peoples. (p. 11-12)
\end{abstract}

Mitchell (2002) points to contributions from African American rap artists like Koolism and Trey in order to show how black ethnic identity markers have evolved into brown ethnic identity markers and have been absorbed into Māori popular performance. Tania Kopytko ${ }^{2}$ claims that the association of Māori youth with internationalised black identity performances compensates in part for the lack of a thorough knowledge of Māori culture (Mitchell, p.283). These statements raise complex issues around acculturation, assimilation, and identity in the context of Tino Rangatiratanga, but even so it is clear that the African American music has a significant influence on popular contemporary Māori music.

\title{
Why is it necessary to celebrate tuawahine?
}

Yates-Smith (1988) and Mikaere (2003) both discuss the ways residual traces of centuries of European domination continue to inform how Maori women are viewed and how such narratives

2 Executive Director of DANZ (Dance Aotearoa New Zealand).

Te Kaharoa, Special Edition, Ka Haka - Empowering Performance: Mãori and Indigenous Performance Studies Symposium, vol. 9, 2016, 
serve to engender a fictitious sense of European supremacy. So entrenched is Eurocentrism in daily life, so prevalent, even after the so-called end of colonisation, that it often goes unremarked while continuing to pervade modern-day representational practices. Pihama and Johnson $(1994,1995)$ discuss how the Eurocentric dominant discourses continue to inform contemporary representation of Māori women. They investigate the notion of dualisms that connect gendered binaries with racist essentialist discourses of white supremacy.

The imaging of difference and race by the dominant culture has contributed significantly to how Māori women are perceived, to the ways in which Māori knowledge, language and culture has been constructed, and to the ways in which Māori have been treated and associated with substandard living standards, poverty, crime, cultural and social deficiencies including racialised traits like limited intellectual capacity and the warrior gene. Pihama (1994) points out the danger of Māori representation being controlled and influenced by the dominant power:

If there are images about you but they are negative and insensitive so that they are saying you are not good, that is dangerous ... if there are images that are about you and they are untrue, that is very dangerous.

\section{Who is Te Aitu o Te Rangi?}

I am a fifth generation granddaughter of Te Aitu o Te Rangi. According to our whānau histories, Te Aitu o Te Reangi was born in 1820 to Te Whatahoronui and Aromea in present day Martinborough which was then known as Te Ureta. Her people were of Ngati Moe at Papawai, in the Wairarapa which is a hapu of Rangitāne and Ngati Kahungunu. Te Aitu-o-te-Rangi literally means "misfortune of the sky"; she was given this name, because she was born on a day when the sky was red/orange 
in colour. When she was fourteen, Te Rauparaha of Ngāti Toa invaded Wairarapa and killed her father. As a consequence of her noble blood line, she was forced to become one of Te Rauparaha slave wives and taken to Kapiti Island with her cousin, Wi Kingi Tu-te-pakihi-Rangi where she was held hostage. At age sixteen, she met John Milsome Jury, who was an expert in whaling. He was enchanted by the beautiful princess. The feeling was mutual, and the couple constructed a plan to escape from Kapiti Island and return to the Wairarapa. John Jury stole a small whaleboat and rowed to a pre-arranged meeting place to collect Te Aitu. They headed the boat across Cook Straight towards Palliser Bay. All night they rowed determined to reach their destination. Into the big southern bay they sailed, with Te Aitu pointing the way towards the Lake Onoke bar.

In the meantime, back at Kapiti Island, an infuriated Te Rauparaha had woken to find his prisoner disappeared. The warlord beckoned sixty of his most fierce soldiers and propelled his big war canoe towards Cape Turakirae. However, they were unfortunate on approach to the Onoke bar, for the turbulence threw many combatants overboard and they were drowned. Yet Te Rauparaha demanded his warriors to carry on the pursuit. As John Jury and Te Aitu arrived at the Ruamahanga River, they were terrified to hear the triumphant paddling song of the Ngati Toa - Te Rauparaha's war canoe. In fear, Te Aitu directed Jury to pull into a discreet backwater behind a slight totaraclad landmass. The boat was marooned, screened by a tangle of tumbled trees, and they hid in the thick bush at the water's edge. Nearer came the throbbing chant as the warriors drove the big canoe on. Breathlessly the pair waited amongst the trees - wondering if their pursuers would take the channel. Quivering, Te Aitu cleaved to John Jury as Te Rauparaha and his war canoe hurried past their island refuge and on up the river. For three days, they dared not light a fire, or travel, for fear their sly adversary was lying in wait for them. Then, to their enormous relief, they spied the big canoe traveling silently down

Te Kaharoa, Special Edition, Ka Haka - Empowering Performance: Māori and Indigenous Performance Studies Symposium, vol. 9, 2016, 
river. In the stern sat Te Rauparaha as he made his way back to his homeland.

With the hazard past, Te Aitu showed John Jury the way up the Ruamahanga and into the Waiohine River, and they came ashore at the Kuratawhiti clearing. At last they were at their journey's end: Te Aitu's family birthplace. She nodded to the land about them to show that what was hers was his and would become their future home. Te Aitu then went to the base of a mature totara, pulled out a flax kete and took from it a greenstone hoe which her people had hurriedly placed there before fleeing from Te Rauparaha's assault. This was a physical mark of family possession. John Jury and Te Aitu-o-te-Rangi were wed and had four children. The first was Hoani Te Whatahoro who became a prolific writer on Māori traditions and customs, an advocate in the Native Land Court, and the President of the first Māori government movement located at Papawai. A daughter, Annie Eliza Te Haereaute, who married Joseph Oates, was born in 1846, and another son, Charles Joseph Te Rongotumamao, in 1850. A male child, born in 1854, did not survive. Te Aitu died in 1854.

I wrote two compositions about Te Aitu o Te Rangi, to ensure that she is remembered and acknowledged for the significant contribution that she made to the people of Wairarapa. She is a Tuawahine. The desire to perpetuate her story is insistent. Another resolve is to acknowledge and elevate Māori archetypes of the heroine such as Tuawahine. Te Aitu o Te Rangi is a positive role model. She was a woman of mana because of her royal lineage. At a young age she demonstrated physical and mental strength amidst impending death on the rocky waters of Wairarapa. She was the mother of one of the most reputed writers of Māori lore and tikanga.

Māori heroines empower young Māori girls as they can see themselves in her, relate to her, and connect to her. Te Aitu is someone that they can aspire to be like, and she gives them courage to embrace and celebrate being a Māori girl. Māori archetypes of the heroine are necessary to challenge the West 
notions of heroines which celebrate a model of women that is based on foreign episteme. Contemporary composition is a strategic approach to challenge issues regarding race, gender, and politics and is part of the Tino Rangatiratanga resolve.

\section{Retelling our stories: the decolonisation obligation}

Contemporary Māori composition provides a space to challenge Western discourse, especially European ideas of Māori womanhood. A composition that celebrates the life of Tuawahine, within the context of Māori epistemological values, ethos and principles, can act not only to acknowledge the role of Tuawahine in the construction of whānau, hapu and iwi, but also to highlight connections with Atua Wahine. Composition provides an opportunity to talk back, to assert difference, and to challenge the dominant discourse. Contemporary music shares a similar role as traditional composition in the sense of providing a space of resistance. It also provides an opportunity to create consciousness about issues that are affecting Māori through identifying, acknowledging and analysing political issues and their effects on Māori women as part of a decolonisation agenda.

Afro-Caribbean scholar Frantz Fanon (1952), in Black Skin, White Masks, outlines the impact of colonisation on the African spirit, mind, and intelligence. Fanon states that the African was taught to honour white skin as the symbol of a superior culture and civilisation. To see the world through the lens of European eyes meant that Africans perceived themselves as base, savage, and less than fully human. Moana Jackson (1995), among others, refers to this effect as the 'colonisation of the soul' and extends Fanon's view to Aotearoa:

For the Māori the attack on their soul was so terrible it led to a weakening of faith in all things which had nourished it. The demeaning of the values which cherished it, the language which gave 
it voice, the law which gave it order, and the religion which was its strength, was an ongoing process which ultimately affected the belief of Māori in themselves. (p.11)

Composition is an opportunity to connect with the past, present and future and to speak to issues regarding gender, race, and politics that are relevant to today and tomorrow. Composition is a taonga tuku iho, a powerful medium to contest kaupapa that affects Māori. In Tonkin's words:

People talk of the past so as to distinguish now from a different then. At the same time, ever now is the consequence of many thens ... What goes on now is interpreted from previous knowledge, from memory. The present we live is built from past events. (1995: 9)

Re-telling our history our way is essential to the future, to the preservation of our principles, values, lore, and philosophy.

\section{Conclusion}

The power of composition to rejuvenate values and principles of Mana Wahine is still yet to be fully realized. Through the medium of contemporary song I re-tell the story of my tipuna wahine Te Aitu o Te Rangi. I have aimed in this article to identify the potential of composition to address issues regarding gender, race and politics. Composition is an innovative and strategic way of transforming traditional knowledge about Mana Wahine into action that is pragmatic and pertinent to today's complex realities. There is great potential located in composition to positively shape representations of Māori women that are positive and grow and nurture the identity and confidence of young Māori girls. 


\section{References}

Allen, B., \& Montell, W.L. (1981). From Memory to History - Using Oral Sources in Local Historical Research. Nashville: American Association for State and Local History.

Best, E. (1924). Māori religion and mythology part $l l$. Wellington, New Zealand: Government Printer.

Eisner, M. (2004). The Essential Neruda - Selected Poems. San Francisco: City Lights Books and Fundación Pablo Neruda.

Fanon, F. (1952). Black Skin, White Masks. London: Penguin.

Jackson, M. (1995). "Cultural Justice: A Colonial Contradiction or a Rangatiratanga Reality?" in Judge F W M McElrea (ed) Rethinking Criminal Justice Vol 1: Justice in the Community. Auckland: Legal Research Foundation.

Johnston, P. \& Pihama, L. (1994). 'The marginalisation of Maori women', in Hecate 20.2, pp. 83-97.

Johnston, P. \& Pihama, L. (1995). 'What counts as difference and what differences count: Gender, Race and the Politics of Difference' in Irwin, K., Ramsden, I. \& Kahukiwa, R. (eds) (1995) Toi Wahine: The Worlds of Maori Women. Auckland, NZ: Penguin Books, pp 75-86.

Ka'ai-Mahuta, R. (2006). He kupu tuku iho mō tēnei reanga: A critical analysis of waiata and haka as commentaries and archives of Mãori political history (Unpublished Doctoral Thesis). Auckland University of Technology, Auckland, New Zealand.

McRae, J. (2004). 'Ngā tuhituhinga reo Māori - Literature in Māori'. In T. M. Ka'ai, J. C. Moorefield, M.P.J. Reilly \& S. Mosley (Eds.). Ki te Whaiao: An Introduction to Māori Culture and Society (pp.133-138). Auckland: Pearson Education.

Mikaere, A. (2003). The Balance Destroyed: The Consequences for Maori Women of the Colonisation of Tikanga Maori. Auckland: The Indigenous Research Institute for Maori and Indigenous Education.

Mitchell, T. (Eds.) (2002). Global Noise: Rap and Hip Hop Outside the USA. Middletown, CT: Wesleyan University Press.

Pihama, L. (1994). 'Are films dangerous: A Maori women's perspective on The Piano'. In Hecate: An interdisciplinary journal of women's liberation, Hecate Press. Brisbane, Australia: The University of Queensland.

Royal, T. A. (2002). Indigenous worldviews: A comparative study - A report on research in progress. Wellington: Winston Churchill Memorial Trust. 
Smith, L (1999). Decolonizing Methodologies: Research and Indigenous Peoples. London: Zed Books.

Tonkin, E. (1995). Narrating Our Pasts - The Social Construction of Oral History. Camberwell: Penguin.

Yates-Smith, G. R. A. (1988). Hine! E Hine! Rediscovering the feminine in Māori spirituality (Unpublished Doctoral thesis). The University of Waikato, Hamilton, New Zealand.

Sophronia Smith o Wairarapa, Kahungunu ki Wairarapa, Rakaipaaka, Rongomaiwahine. I am a singer, performer, song writer, composer and documentary maker and have won national and international awards for these gifts. I am a passionate Social Work adult educator and researcher, and explore song, film, movie, and performance as pedagogy when exploring issues such as power, mana motuhake, bi-culturalism, race, and inter-generational trauma and healing. I currently work for Te Wānanga o Aotearoa in the role Kaihāpai Rangahau and support staff engaged in rangahau which includes MA, PhD, iwi rangahau, publications etc. I am enrolled in a creative $\mathrm{PhD}$ at Waikato University entitled "Voices from the future speaking to the past: Decolonizing western constructions of the female heroine through honouring, affirming and revitalizing stories of Tuawahine from Rangitane o Wairarapa and Kahungunu ki Wairarapa”.

Te Kaharoa, Special Edition, Ka Haka - Empowering Performance: Māori and Indigenous Performance Studies Symposium, vol. 9, 2016, 